\title{
Penerapan Pembelajaran Sains Berbasis Inquiry Based Learning Terintegrasi Nature of Science Terhadap Literasi Sains
}

\author{
Utaria Mutasam $^{1}$, Ibrohim ${ }^{1}$, Herawati Susilo ${ }^{1}$ \\ ${ }^{1}$ Pendidikan Biologi-Universitas Negeri Malang
}

\begin{tabular}{l}
\hline INFO ARTIKEL \\
\hline Riwayat Artikel: \\
Diterima: $17-05-2019$ \\
Disetujui: $18-10-2020$ \\
\hline
\end{tabular}

\section{Kata kunci:}

inquiry based learning; nature of science; literasi sains; pembelajaran berbasis inkuiri, nature of science;

literasi sains

\section{ABSTRAK}

Abstract: The aim of research was to describe the effect of the application of InquiryBased Learning (IBL) integrated the Nature of Science (NOS) on student scientific literacy. The implementation design used was nonrandomized control group pretestposttest design with research subjects using two classes namely VII C (control class) and VII D (experimental class) of SMP Laboratorium UM. Data was collected using a scientific literacy test and then analyzed descriptively and statistically and the results are that the application IBL integrated NOS influences students' scientific literacy with level of scientific literacy of students is included in the nominal and functional categories.

\begin{abstract}
Abstrak: Penelitian bertujuan untuk mengetahui pengaruh penerapan pembelajaran sains berbasis Inquiry Based Learning (IBL) terintegrasi Nature of Science (NOS) terhadap literasi sains siswa dengan menggunakan desain implementasi nonrandomized control group pretest-posttest design pada subjek penelitian siswa kelas VII C (kelas kontrol) dan VII D (kelas eksperimen) di SMP Laboratorium UM. Data dikumpulkan dengan menggunakan tes uraian literasi sains lalu dianalisis secara deskriptif dan statistik yang menunjukkan hasil bahwa penerapan pembelajaran sains berbasis IBL terintegrasi NOS berpengaruh terhadap literasi sains siswa yang mana berada pada tingkat nominal dan fungsional.
\end{abstract}

\section{Alamat Korespondensi:}

Utaria Mutasam

Pendidikan Biologi

Universitas Negeri Malang

Jalan Semarang 5 Malang

E-mail: utariamutasam@gmail.com

Salah satu faktor yang menentukan maju atau tidaknya suatu negara adalah pendidikan sebab melalui pendidikan, diharapkan dapat menghasilkan sumberdaya manusia yang berkualitas sehingga tujuan pendidikan nasional yang salah satunya untuk membentuk SDM yang berkualitas dapat terlaksana (BSNP, 2010). Melalui pendidikan terutama pembelajaran sains diharapkan siswa dapat memahami dan menggunakan konsep dari sains dan teknologi yang ada di sekitar mereka sehingga literasi sains memiliki peran penting dalam kehidupan dan menjadi keharusan bagi setiap orang (Rusilowati, et al., 2016).

Literasi sains merupakan aspek yang sangat penting dalam pembelajaran sains (Vayssettes, 2016) dan telah digunakan pada literatur selama lebih dari empat dekade. Literasi sains memiliki makna yang beragam, salah satunya dianggap sebagai pengetahuan sains (Education at a Glance, 2014) dan tujuan dari pendidikan sains (Bybee, et al., 2009; Holbrook, et al., 2009) karena salah satu tujuannya untuk meningkatkan literasi sains (Holbrook, 2010). Literasi sains juga didefinisikan sebagai kemampuan dalam memilah beberapa fakta dari berbagai peristiwa yang didapat (Impey, 2013) dan dapat digunakan oleh masyarakat untuk beradaptasi dengan cepatnya perubahan dunia (Holbrook et al., 2009). Dua hal penting dari literasi sains yakni peran penting pengetahuan sains dalam pembelajaran di sekolah dan kegunaan literasi sains di masyarakat (Ogunkola, 2013). Literasi sains disertai dengan pemikiran yang kritis akan membuat seseorang mampu menggunakan pengetahuan yang dimiliki untuk meningkatkan kualitas hidup seseorang (Holbrook et al., 2009; Reis \& Galvao, 2009). Hal esensial dari literasi sains adalah kemampuan untuk mengaplikasikan pemahaman sains pada kehidupan nyata yang melibatkan sains dan penilaiannya berfokus pada kompetensi ilmiah siswa yang harus diketahui dan dilakukan dalam konteks individu, sosial dan global (Bybee et al., 2009; Vayssettes, 2016).

Akan tetapi, fakta yang dijumpai menunjukkan bahwa literasi sains siswa tergolong rendah. Fakta tersebut didukung oleh data yang menyebutkan bahwa literasi sains siswa SMP kota Malang pada aspek penggunaan pengetahuan sains tergolong sangat rendah (22,8\%) namun pada aspek pengetahuan konsep siswa tergolong relatif tinggi (96,1\%) (Pantiwati \& Husamah, 2014). Rendahnya literasi sains disebabkan oleh berbagai faktor, di antaranya kondisi pembelajaran yang hanya menekankan pada hafalan dan kurang menekankan pada proses dimana siswa melakukan penyelidikan dan penilaian IPA yang hanya 
menekankan pada dimensi konten dan melupakan dimensi konteks serta proses (Firman, 2009). Beberapa fakta yang didapatkan dapat dijadikan acuan untuk melakukan perbaikan dalam pembelajaran sains yang selama ini sudah dilakukan. Sains merupakan sebuah proses dan tubuh dari ilmu pengetahuan yang progresif dan universal (Sund \& Throwbridge, 2009) serta merupakan suatu metode untuk menyelidiki berbagai fenomena alam yang terjadi (Koballa \& Chiappetta, 2010). Sains bukan hanya kumpulan pengetahuan tentang alam, tetapi terdiri dari tiga unsur utama, yakni sains sebagai produk (pengetahuan ilmiah dan teknologi), sains sebagai proses (metode ilmiah) (Rahayu, 2016; Sheeba, 2013) dan sains sebagai sikap (Rahayu, 2016).

Pembelajaran sains memiliki tujuan utama untuk membuat siswa berpikir secara ilmiah dalam pembelajaran yang berbasis penyelidikan (Chinn \& Malhotra, 2002). Rancangan pembelajaran sains yang dikembangkan menghasilkan perangkat pembelajaran yang berbasis Inquiry Based Learning (IBL) dengan tujuh sintaks pembelajaran, meliputi (1) eksplorasi fenomena, (2) membuat pertanyaan, (3) merancang penyelidikan, (4) melakukan penyelidikan, (5) menganalisis data dan bukti, (6) membangun, dan (7) mengomunikasikan pengetahuan baru (Llewellyn, 2013). Model pembelajaran tersebut dipilih sebab dalam proses pembelajarannya siswa dilibatkan secara penuh untuk melakukan penyelidikan sebagai bentuk penerapan metode ilmiah (Khan \& Iqbal, 2011) dan menekankan pada proses siswa mencari tahu dan menyelidiki (Joyce \& Weil, 2000). Perangkat pembelajaran yang dikembangkan diiintegrasikan dengan Nature of Science (NOS) (Lederman, 2007) agar siswa memahami sains secara benar dan bermakna (Clough, 2007), dan mampu mengaplikasikannya dalam kehidupan (Chinn \& Malhotra, 2002; Lederman, 2007). Terkait sangat pentingnya literasi sains dimiliki oleh siswa maka perlu dilakukan pengkajian terhadap aspek-aspek literasi sains apa saja yang dimiliki siswa. Terdapat tiga aspek yang diukur dalam literasi sains, yaitu identifikasi isu ilmiah, mendeskripsikan fenomena ilmiah, dan menggunakan bukti ilmiah (Bybee et al., 2009).

\section{METODE}

Penelitian ini merupakan lanjutan dari penelitian pengembangan pembelajaran sains berbasis IBL terintegrasi NOS yang menghasilkan perangkat pembelajaran yang sudah dinyatakan sangat valid dan layak untuk diimplementasikan. Penelitian dilakukan pada bulan Januari-Februari 2019 dengan jumlah pertemuan sebanyak 10 kali pertemuan. Desain implementasi perangkat pembelajaran yang digunakan yaitu nonrandomized control group pretest-posttest design dengan populasi penelitian siswa kelas VII SMP Laboratorium UM tahun ajaran 2018/2019. Berdasarkan uji kesetaraan yang telah dilakukan pada empat kelas yakni VII B, VII C, VII D, dan VII F didapatkan hasil yang setara sehingga penentuan subjek penelitian dilakukan dengan metode simple random sampling. Dari ke empat kelas tersebut, kelas VII C dan VII D terpilih sebagai subyek dalam penelitian ini. Tes literasi sains dalam penelitian ini berjumlah 11 soal uraian untuk dua materi yaitu materi energi dan sistem organisasi kehidupan yang telah diuji coba dan dinyatakan valid serta reliabel. Analisis deskriptif dilakukan dengan mengkategorikan jawaban siswa ke beberapa kategori kemudian dipersentasekan sesuai kategori yang ada. Lalu juga dilakukan analisis data literasi sains dengan analisis statistik kuantitatif yang terdiri atas uji normalitas, uji homogenitas, lalu analisis data akhir berupa pengujian hipotesis (uji analisis kovarian satu jalur) dengan taraf signifikansi $\alpha=0,05$.

\section{HASIL}

Rerata nilai literasi sains pada saat sebelum dan sesudah pembelajaran sains berbasis IBL terintegrasi NOS dilaksanakan, tertera pada tabel 1 .

Tabel 1. Rerata Nilai Literasi Sains

\begin{tabular}{clcc}
\hline No & Kelas & Pretest & Posttest \\
\hline 1 & Eksperimen & 15 & 25 \\
2 & Kontrol & 14 & 19 \\
\hline
\end{tabular}

Berdasarkan uji normalitas Kolmogorov-Smirnov menggunakan SPSS 25 diketahui bahwa nilai pretest dan posttest literasi sains memiliki nilai signifikansi/p $(0,200$ dan 0,143$)>\alpha(0,05)$, yang berarti data terdistribusi normal dan hasil ujinya dapat dilihat pada tabel 2 .

Tabel 2. Hasil Uji Normalitas Nilai Pretest dan Posttest Literasi Sains

\begin{tabular}{cccccc}
\hline No & Variabel & Statistic & Sig (2-tailed) & Alpha & Keterangan \\
\hline 1 & Pretest literasi sains & 0,107 & 0,200 & 0,05 & Normal \\
2 & Posttest literasi sains & 0,137 & 0,143 & 0,05 & Normal \\
\hline
\end{tabular}

Pada uji homogenitas dengan uji Levene menggunakan bantuan SPSS 25 menunjukkan bahwa nilai literasi sains memiliki nilai signifikansi/p $(0,085$ dan 0,205$)>\alpha(0,05)$ yang berarti keseluruhan data homogen seperti yang tertera pada tabel 3. 
Tabel 3. Hasil Uji Homogenitas Nilai Pretest dan Posttest Literasi Sains

\begin{tabular}{clccccc}
\hline No & \multicolumn{1}{c}{ Variabel } & Nilai F & df & Sig & Alpha & Keterangan \\
\hline 1 & Pretest literasi sains & 3060 & 60 & 0,085 & 0,05 & Homogen \\
2 & Posttest literasi sains & 1,642 & 60 & 0,205 & 0,05 & Homogen \\
\hline
\end{tabular}

Berdasarkan hasil uji analisis kovarian menggunakan SPSS 25 diperoleh nilai signifikansi/p $(0,003)<\alpha(0,05)$ yang berarti pembelajaran sains berbasis IBL terintegrasi NOS berpengaruh terhadap literasi sains siswa. Ringkasan hasil perhitungan menggunakan uji analisis kovarian tertera pada tabel 4.

Tabel 4. Hasil Uji Analisis Kovarian Pembelajaran Sains Berbasis IBL Terintegrasi NOS Terhadap Literasi Sains

\begin{tabular}{lrrrrr}
\hline Sumber Variasi (SV) & Jumlah Kuadrat & Df & Rerata Kuadrat (RK) & \multicolumn{1}{c}{ F } & Sig. (p) \\
\hline Corrected Model & $1065.391^{\mathrm{a}}$ & 2 & 532.695 & 11.466 & .000 \\
Intercept & 5916.879 & 1 & 5916.879 & 127.363 & .000 \\
PRETEST & 536.987 & 1 & 536.987 & 11.559 & .001 \\
KELAS & 450.075 & 1 & 450.075 & $\mathbf{9 . 6 8 8}$ & $\mathbf{. 0 0 3}$ \\
Error & 2740.948 & 59 & 46.457 & & \\
Total & 34567.000 & 62 & & & \\
Corrected Total & 3806.339 & 61 & & & \\
\hline
\end{tabular}

Selanjutnya dilakukan uji rerata terkoreksi untuk mengetahui rerata kelas yang tertinggi antara dua kelas yang menjadi subyek dalam penelitian. Ringkasan rerata terkoreksi nilai literasi sains siswa tertera pada tabel 5.

Tabel 5. Ringkasan Rerata Terkoreksi Nilai Literasi Sains

\begin{tabular}{lcccccc}
\hline Kelas & Pretest $\mathbf{( X i )}$ & Rerata & Penyimpangan & Koreksi & Posttest & Rerata Terkoreksi \\
\hline Eksperimen & 15 & 14,5 & 0,5 & 0,13 & 25 & 24,87 \\
Kontrol & 14 & 14,5 & $-0,5$ & $-0,13$ & 19 & 19,13 \\
\hline
\end{tabular}

Berdasarkan tabel 5 menunjukkan bahwa nilai rerata terkoreksi literasi sains siswa yang tertinggi adalah kelas eksperimen yang diberi perlakukan berupa penerapan pembelajaran sains berbasis IBL terintegrasi NOS. Berikut adalah grafik persentase jawaban siswa berdasarkan kategori literasi sains pada dua materi yakni materi energi dan sistem organisasi kehidupan.

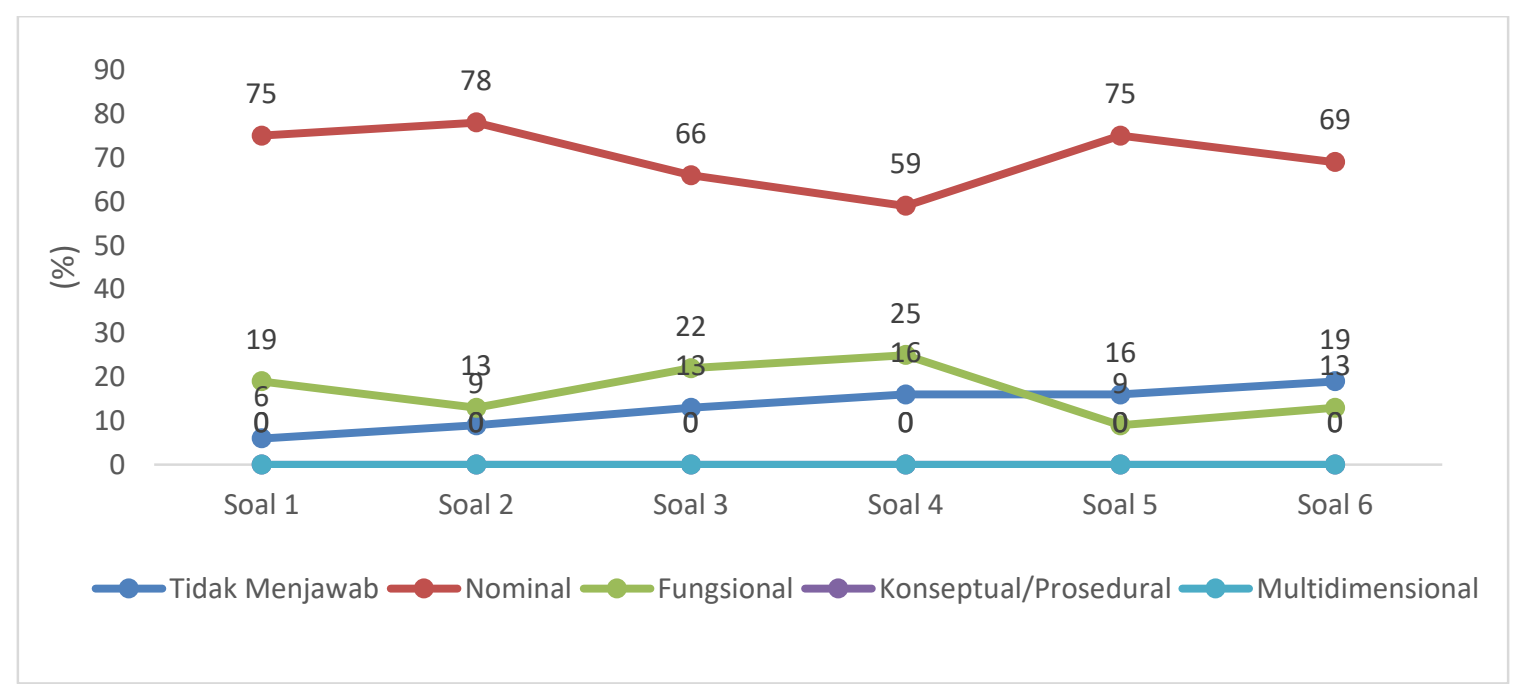

Gambar 1. Persentase Tingkat Jawaban Siswa Menurut Kategori Literasi Sains pada Materi Energi 


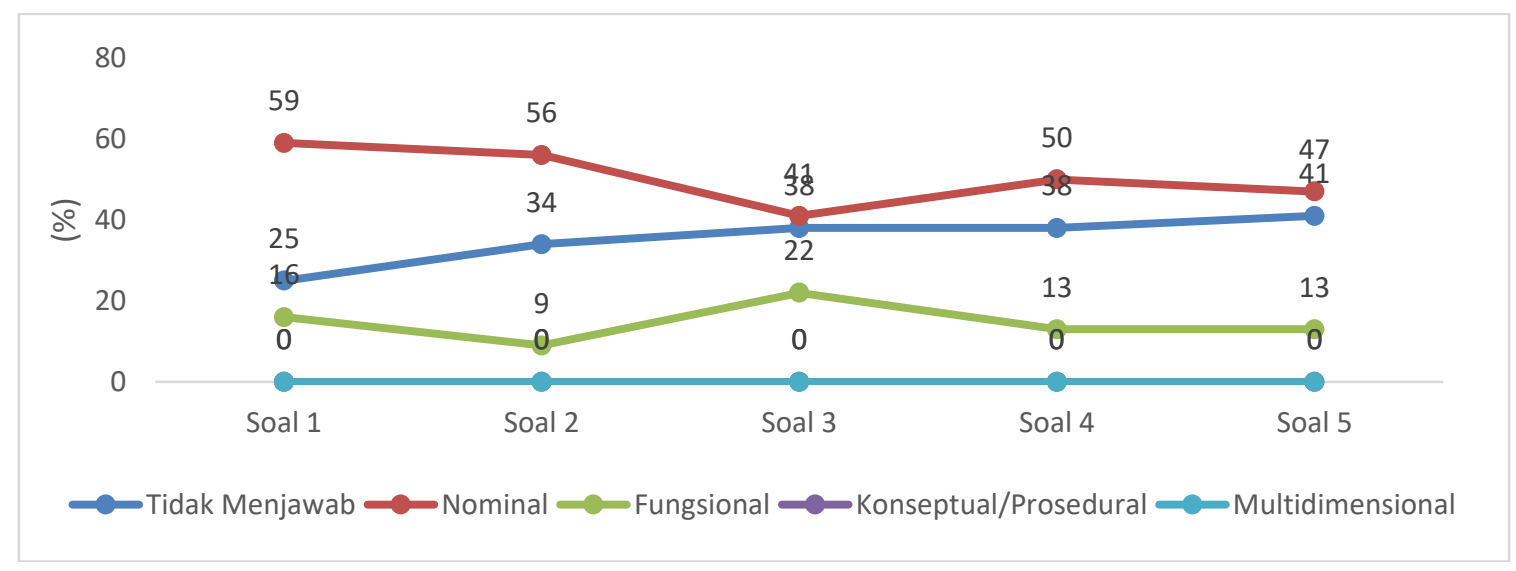

\section{Gambar 2. Persentase Tingkat Jawaban Siswa Menurut Kategori Literasi Sains pada Materi Sistem Organisasi Kehidupan}

Hasil tes literasi sains pada dua materi yang berbeda memperlihatkan bahwa jawaban siswa didominasi oleh kategori nominal, fungsional, dan tidak menjawab. Keseluruhan soal literasi sains pada materi energi yang telah diujikan didapatkan rerata persentase tertinggi jawaban siswa pada kategori nominal (70\%), kategori fungsional (17\%), kategori konseptual/prosedural dan multidimensional $0 \%$ serta kategori tidak menjawab $13 \%$. Sementara itu, untuk tes literasi sains pada materi sistem organisasi kehidupan didapatkan rerata persentase tertinggi jawaban pada kategori nominal (51\%), kategori fungsional (15\%), kategori konseptual/prosedural dan multidimensional 0\% serta kategori tidak menjawab $34 \%$.

\section{PEMBAHASAN}

Berdasarkan analisis data yang telah dilakukan, didapatkan temuan bahwa nilai signifikansi/p $(0,003)<\alpha(0,05)$, yang berarti pembelajaran sains berbasis IBL terintegrasi NOS berpengaruh dalam meningkatkan literasi sains siswa pada kelas eksperimen. Hal tersebut dapat terjadi sebab tiga kompetensi ilmiah dalam literasi sains yang diukur pada penelitian ini terfasilitasi dalam kegiatan pembelajaran sains berbasis IBL terintegrasi NOS yang diterapkan. Saat kegiatan pembelajaran mengeksplorasi fenomena dan memfokuskan pertanyaan dilakukan, siswa didorong untuk mengobservasi dan mengidentifikasi isu-isu ilmiah yang memungkinkan untuk diselidiki oleh siswa, membuat jawaban sementara dari fenomena yang ada sebagai bekal awal sebelum mulai melakukan penyelidikan ilmiah. Selanjutnya pada kegiatan pembelajaran merencanakan \& melakukan penyelidikan serta menginterpretasi data dan bukti, siswa dilatih untuk mampu mendeskripsikan dan memberikan penjelasan terkait fenomena ilmiah dengan menerapkan konsep yang telah didapat. Lalu pada kegiatan pembelajaran membangun dan mengomunikasikan pengetahuan baru, siswa didorong untuk mampu menggunakan dan mengidentifikasi asumsi, bukti dan alasan yang didapat dari penyelidikan untuk menafsirkan bukti ilmiah dan membuat kesimpulan.

Selain difasilitasi oleh kegiatan pembelajaran berbasis IBL, peningkatan literasi sains siswa juga didukung oleh diintegrasikannya perangkat pembelajaran IBL tersebut dengan beberapa indikator NOS, diantaranya (1) investigasi ilmiah menggunakan berbagai metode, (2) bukti empiris menjadi dasar pengetahuan ilmiah, (3) fenomena dijelaskan dari berbagai aspek sains, dan (4) cara untuk mengetahui sesuatu adalah melalui sains. Beberapa indikator NOS tersebut dieksplisitkan dalam setiap kegiatan pembelajaran yang dilakukan. Hal tersebut membuat siswa menjadi terlatih dan memiliki pemahaman yang mendalam terkait materi yang dipelajari. Pemahaman siswa terkait materi pembelajaran tidak dapat tercapai ketika siswa tidak memahami NOS dan penyelidikan yang dilakukannya (Lederman, et al., 2013). Hasil ini senada dengan penelitian dari Gormally, et al., (2009) dan Saefullah et al., (2017) bahwa pembelajaran sains berbasis inkuiri berpengaruh terhadap literasi sains siswa. Dengan dieksplisitkannya beberapa indikator NOS dalam pembelajaran sains berbasis IBL, siswa akan lebih memahami sumber dan batasan dari pengetahuan sains sehingga mereka akan lebih siap untuk membuat keputusan tentang isuisu sosial yang berbasis ilmiah. Secara singkat dapat dijelaskan bahwa pemahaman siswa terkait NOS dan penyelidikan ilmiah diyakini sebagai komponen penting dari terbentuknya literasi sains (Lederman et al., 2013)

Selanjutnya analisis deskriptif dilakukan pada jawaban siswa dalam tes literasi sains dengan mengkategorikannya menjadi beberapa kategori tertentu untuk mengetahui tingkatan literasi sains yang dimiliki siswa. Kategori literasi sains dari jawaban siswa tertera pada tabel 6. 
Tabel 6. Kategori Jawaban Siswa pada Tingkat Literasi Sains (Soobard \& Rannikmae, 2011:138)

\begin{tabular}{ll}
\hline Kategori & \multicolumn{1}{c}{ Deskripsi } \\
\hline Nominal & $\begin{array}{l}\text { Siswa menyetujui pendapat orang lain tanpa melibatkan pemikiran sendiri disertai dengan penulisan } \\
\text { konsep yang belum mampu dibenarkan atau mengalami kesalahan dalam memahami suatu konsep. }\end{array}$ \\
Fungsional & $\begin{array}{l}\text { Siswa belum mampu membuat hubungan antar konsep karena keterbatasan informasi yang dimiliki } \\
\text { sehingga tidak mampu memberikan pendapat terkait fenomena yang disajikan. }\end{array}$ \\
Konseptual/ & $\begin{array}{l}\text { Siswa memahami hubungan antar konsep sehingga mampu menganalisis dan memberikan solusi terkait } \\
\text { masalah yang diberikan. } \\
\text { Pultidimensional } \\
\text { Siswa mampu mengaplikasikan pemahaman yang didapat dari hubungan antar konsep dengan kejadian } \\
\text { yang dialami setiap hari. }\end{array}$ \\
\hline
\end{tabular}

Secara umum, dari gambar 1 dan 2 terlihat bahwa kategori nominal dan fungsional memiliki persentase yang tinggi dibanding kategori yang lain pada jawaban siswa. Sementara itu jawaban siswa pada kategori konseptual/prosedural dan dimensional memiliki persentase nol. Kedua grafik tersebut juga menunjukkan bahwa persentase siswa yang tidak mampu menjawab tes cukup besar yakni pada kisaran 13-34\%. Jawaban yang diberikan siswa terhadap masalah/fenomena yang disajikan hanya terbatas pada pernyataan kesetujuan/ketidaksetujuan, penjelasan yang diberikan hanya terbatas pada pemikiran sendiri tanpa memahami konsep yang ada, belum mampu memberikan contoh dan masih banyak menggunakan istilah yang salah sehingga jawaban siswa hanya berada pada tingkat nominal. Jawaban dalam kategori fungsional yang memiliki persentase tidak melebihi $20 \%$ menunjukkan bahwa sebagian kecil siswa sudah mampu mengingat konsep atau informasi terkait masalah yang diberikan namun masih kesulitan dalam menggambarkan hubungan antar konsep. Tidak adanya siswa yang mampu menjawab dalam kategori konseptual/prosedural atau multidimensional mengindikasikan bahwa siswa mengalami kesulitan menghubungkan beberapa konsep yang dimilikinya untuk kemudian digunakan dalam menyelesaikan suatu masalah dan pengambilan keputusan pada situasi kehidupan sehari-hari. Kesulitan yang dialami siswa kemungkinan disebabkan dari pertanyaan literasi sains yang belum menggabungkan konteks sosial yang dialami siswa sehari-hari (Soobard \& Rannikmae, 2011) atau siswa mengalami kesulitan dalam memahami fenomena yang diberikan sehingga pemikiran siswa tidak berkembang. Persentase yang cukup besar pada kategori tidak menjawab mengindikasikan bahwa siswa mengalami kesulitan dalam memahami soal sehingga siswa belum mampu menuliskan jawaban terbaik mereka dari soal yang diujikan. Hasil yang didapat sesuai dengan Odja \& Payu, (2014) yang menyatakan tingkat literasi sains kelas VII SMP masih berada pada kategori nominal dan fungsional.

Analisis dari jawaban literasi sains siswa menunjukkan bahwa mereka kesulitan menggunakan pengetahuan yang dimiliki untuk diaplikasikan dalam situasi kehidupan sehari-hari. Siswa hanya mengetahui beberapa fakta namun belum mampu mencari hubungan antar fakta sehingga kesulitan dalam mengomunikasikan dan mengaplikasikan pemikiran mereka (Basam, et al., 2017; Hayat \& Yusuf, 2010). Rendahnya kemampuan literasi sains siswa dapat diatasi dengan lebih menekankan kegiatan penyelidikan sains yang lebih mengembangkan penjelasan dan argumen untuk menjelaskan fenomena alam disertai dengan argumentasi dan data-data yang terukur dan akurat (Braaten \& Windschitl, 2011; Campbell, et al., 2013).

\section{SIMPULAN}

Pembelajaran sains berbasis IBL terintegrasi NOS berpengaruh terhadap literasi sains siswa dengan kategori nominal dan fungsional yang berarti siswa sudah mampu mengingat dan menggunakan konsep-konsep yang dimiliki namun belum mampu memberikan pernyataan yang tepat terhadap masalah/fenomena yang ada dan belum mampu menghubungkan konsepkonsep yang dimiliki sebelumnya. Terkait masih besarnya persentase siswa yang belum bisa memberikan jawaban pada tes literasi sains, diharapkan ke depannya akan lebih banyak peneliti yang mengembangkan instrumen yang lebih relevan dengan konteks sosial yang dialami siswa sehari-hari sehingga akan lebih mengembangkan kemampuan literasi sains siswa.

\section{DAFTAR RUJUKAN}

Basam, F., Rusilowati, A., \& Ridlo, S. (2017). Analysis of Science Literacy Learning with Scientific Inquiry Approach in Increasing Science Competence of Students. Journal of Primary Education, 6(3), 174-184.

Braaten, M., \& Windschitl, M. (2011). Working Toward a Stronger Conceptualization of Scientific Explanation for Science Education. Science Education, 95(4), 639-669. https://doi.org/10.1002/sce.20449

BSNP. (2010). Laporan BSNP Tahun 2010. Jakarta: BSNP.

Bybee, R., McCrae, B., \& Laurie, R. (2009). PISA 2006: An Assessment of Scientific Literacy. Journal of Research in Science Teaching, 46(8), 865-883. https://doi.org/10.1002/tea.20333

Campbell, T., Longhurst, M., Duffy, A. M., Wolf, P. G., \& Shelton, B. E. (2013). Science Teaching Orientations and Technology-Enhanced Tools for Student Learning. Research in Science Education, 43(5), 2035-2057. https://doi.org/10.1007/s11165-012-9342-x

Chinn, C. A., \& Malhotra, B. A. (2002). Epistemologically Authentic Inquiry in Schools: A Theoretical Framework for Evaluating Inquiry Tasks. Science Education, 86(2), 175-218. 
Clough, M. P. (2007). Teaching the Nature of Science to Secondary and Post Secondary Students. California Journal of Science Education, 8(2), 31-40.

Firman, H. (2009). Analisis Literasi Sains Berdasarkan Hasil PISA Nasional Tahun 2006. Jakarta: Analisis Literasi Sains Berdasarkan Hasil PISA Nasional Tahun 2006.

Gormally, C., Brickman, P., Hallar, B., \& Armstrong, N. (2009). Effects of Inquiry-based Learning on Students' Science Literacy Skills and Confidence. International Journal for the Scholarship of Teaching and Learning, 3(2). https://doi.org/10.20429/ijsotl.2009.030216

Hayat, B., \& Yusuf, S. (2010). Benchmark International Mutu Pendidikan. Jakarta: Bumi Aksara.

Holbrook, J. (2010). Education through Science as a Motivation Innovation for Science Education for All. Science, 21(2), 8091.

Holbrook, J., Taylor, N., \& Rannikmae, M. (2009). The Meaning of Scientific Literacy. International Journal of Environmental \& Science Education, 4(3), 275-288.

Impey, C. (2013). Science Literacy of Undergraduates in the United States. Organization, People, and Strategies in Astronomy 2 (OPSA 2), 353-364.

Joyce, B., \& Weil, M. (2000). Model of Teaching. New Jersey: Prentice-Hall Inc.

Khan, M., \& Iqbal, M. Z. (2011). Effect of Inquiry Lab Teaching Method on the Development of Scientific Skills Through the Teaching of Biology in Pakistan. Language in India, 11(1), 169-178.

Koballa, \& Chiappetta. (2010). Science Instruction in The Middle and Secondary Schools. USA: Pearson.

Lederman, N. G. (2007). Nature of Science: Past, Present, and Future, Handbook of Research in Science Education. New Jersey: Lawrence Erlbaum.

Lederman, N. G., Lederman, J. S., \& Antink, A. (2013). Nature of Science and Scientific Inquiry as Contexts for the Learning of Science and Achievement of Scientific Literacy. International Journal of Education in Mathematics, Science and Technology (IJEMST), 1(3), 138-147.

Llewellyn, D. (2013). Teaching High School Science through Inquiry and Argumentation (2nd ed.). California: Corwin A SAGE Company.

Odja, A. H., \& Payu, C. S. (2014). Analisis Kemampuan Awal Literasi Sains Siswa pada Konsep IPA. Prosiding Seminar Nasional Kimia. Presented at the Jurusan Kimia FMIPA Universitas Negeri Surabaya. Jurusan Kimia FMIPA Universitas Negeri Surabaya.

Ogunkola, B. (2013). Scientific Literacy: Conceptual Overview, Importance and Strategies for Improvement. Journal of Educational and Social Research, 3(1), 265-274.

Pantiwati, Y., \& Husamah, H. (2014). Analisis Kemampuan Literasi Sains Siswa SMP Kota Malang. Assessment for Quality Education, 158-174.

Rahayu, S. (2016). Mengembangkan Literasi Sains Anak Indonesia melalui Pembelajaran Berorientasi Nature of Science (NOS). Malang: Universitas Negeri Malang.

Reis, P., \& Galvao, C. (2009). Teaching Controversial Socio-Scientific Issues in Biology and Geology Classes: A Case Study. Electronic Journal of Science Education, 13(1), 1-25.

Rusilowati, A., Nugroho, S. E., \& Susilowati, S. M. (2016). Development of Science Textbook Based on Scientific Literacy for Secondary School. Jurnal Pendidikan Fisika Indonesia, 12(2), 98-105.

Saefullah, A., Samanhudi, U., Nulhakim, L., Berlian, L., Rakhmawan, A., Rohimah, B., \& El Islami, A. Z. (2017). Efforts to Improve Scientific Literacy of Students through Guided Inquiry Learning Based on Local Wisdom of Baduy. Jurnal Penelitian Dan Pembelajaran IPA, 3(2), 84-91.

Sheeba, M. N. (2013). An Anatomy of Science Process Skills in The Light of the Challenges to Realize Science Instruction Leading to Global Excellence in Education. India: Educationia Confab.

Soobard, R., \& Rannikmae, M. (2011). Assessing Student's Level of Scientific Literacy Using Interdisciplinary Scenarios. Science Education International, 22(2), 133-144.

Sund, \& Throwbridge. (2009). Teaching Science by Inquiry in the Secondary School. Ohio: Charless E. Merill Publishing Company.

Vayssettes, S. (Ed.). (2016). PISA 2015 Assessment and Analytical Framework: Science, Reading, Mathematic and Financial Literacy. Paris: OECD Publishing. 